\title{
Protective effect of Crocus sativus stamens extract on gentamicin-induced nephrotoxicity and oxidative damage in rat kidney
}

\section{Samira MAMRI ${ }^{1 *}$, Nour Elhouda DAOUDI ${ }^{1}$, Mohamed MARGHICH $^{1}$, Sabir OUAHHOUD $^{1}$, Amine KHOULATI ${ }^{1}$, Mohammed CHOUKRI ${ }^{2}$, Abdeslam ASEHRAOU ${ }^{1}$, Mohamed BNOUHAM ${ }^{1}$, Ennouamane SAALAOUI ${ }^{1}$}

\footnotetext{
${ }^{1}$ Laboratory of Bioresources, Biotechnology, Ethnopharmacology and Health, Department of Biology, Faculty of Sciences, University Mohamed First, Boulevard Mohamed VI; BP: 717; 60 000, Oujda, Morocco.

${ }^{2}$ Biochemistry Laboratory, Central Laboratory Service - CHU, Mohammed VI, Oujda, Morocco.
}

Received - December 11, 2021; Revision - January 20, 2022; Accepted - February 22, 2022

Available Online - February 28, 2022

DOI: http://dx.doi.org/10.18006/2022.10(1).73.82

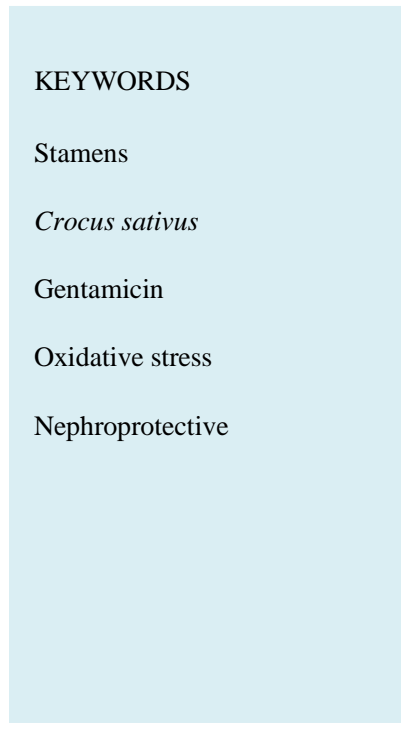

\begin{abstract}
Crocus sativus is a medicinal plant supposedly possessing various biological activities. Currently, it is evaluated only by the medicinal properties of its stigma and many parts of this plant are unused. This work contributes to the valorization of C.sativus stamens by exploring the property of methanolic extract to prevent gentamicin-induced nephrotoxicity in rats. Twenty Wistar rats (weight $250 \pm 30 \mathrm{~g}$ ) were assigned into four equal groups $(n=5)$, and among the assigned groups, group 1 was given only distilled water (Control), group 2 received intraperitoneal (i.p.) injection of gentamicin (GEN) 80 $\mathrm{mg} / \mathrm{kg} / \mathrm{d}$, group 3 received the combination of gentamicin $(80 \mathrm{mg} / \mathrm{kg} / \mathrm{d}$, i.p.) and oral administration of a lower dose of $C$. sativus methanolic extract $(250 \mathrm{mg} / \mathrm{kg} / \mathrm{d}$ ), while the group 4 received the combination of gentamicin $(80 \mathrm{mg} / \mathrm{kg} / \mathrm{d}$, i.p.) and oral administration of a higher dose of $C$. sativus methanolic extract $(500 \mathrm{mg} / \mathrm{kg} / \mathrm{d})$. The injection of gentamicin for the nephrotoxicity induction and post-treatment with methanolic extract was carried out once a day for 15 days. For nephrotoxicity evaluation, biochemical and histopathological analyses were performed. The estimation of serum and urinary creatinine, blood urea nitrogen, sodium levels was carried out with the help of Architect Ci 4100 Analyzer. Oxidative stress was assessed by the determination of renal malondialdehyde (MDA) and catalase (CAT) levels. The results of the study suggested that gentamicin injection induced a significant $(\mathrm{p}<0.01)$ elevation in serum renal
\end{abstract}

* Corresponding author

E-mail: s.mamri@ump.ac.ma (MAMRI Samira)

Peer review under responsibility of Journal of Experimental Biology and Agricultural Sciences.

Production and Hosting by Horizon Publisher India [HPI] (http://www.horizonpublisherindia.in/).

All rights reserved.
All the articles published by Journal of Experimental Biology and Agricultural Sciences are licensed under a Creative Commons Attribution-NonCommercial 4.0 International License Based on a work at www.jebas.org.

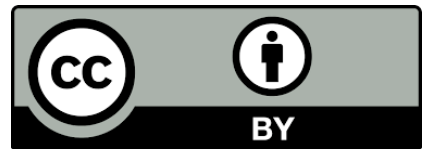


biochemical parameters and oxidative stress indices. The methanolic extract of $C$. sativus significantly $(\mathrm{p}<0.05)$ reduced serum creatinine, urea, and sodium levels, with an improvement in the histopathological results of gentamicin-induced alterations. Furthermore, pretreatment with plant extracts improved hepatic antioxidant status, by the elevation of the CAT and reducing the lipid peroxidation level (MDA) in tissues. The present study suggests that the methanolic extract of $C$. sativus stamens has an interesting nephroprotective effect on the renal lesions induced by GEN in modulating renal parameters and oxidative stress on Wistar rats.

\section{Introduction}

The kidney is an organ at risk for drug toxicity because maximum drugs are eliminated by the kidney either by glomerular filtration (GF) or proximal tubular secretion (Ghuysen 2005). Drug-induced nephropathies are usually lead to the appearance of acute kidney diseases that only persist for the treatment period. However, some chronic kidney disease progress may develop chronic end-stage renal failure and given the high prevalence of acute nephrotoxicity (Karie et al. 2010). Further, aminoglycosides, oxytetracycline, and nonsteroidal types of anti-inflammatory drugs might be nephrotoxic and can induce acute kidney injury (Conly et al. 1994).

Gentamicin (GEN) is an aminoglycoside and is frequently used to inhibit Gram-negative bacteria. Although it is widely used and has a positive effect, but nephrotoxicity is the most important obstacle that limited its use (Reiter et al. 2002; Morales-Alvarez 2020). It was reported that $10-30 \%$ of patients treated with GEN face acute renal failure. Unfortunately, treatment with GEN for more than 7 days shows some symptoms of nephrotoxicity (Ali 2003). GEN causes several histopathological and biochemical changes in the kidney of humans and experimental animals. Some drugs including antioxidant compounds, hormones, minerals, and vitamins play a significant role in the treatment of GEN-induced kidney damage (Ghaznavi et al. 2018; Huang et al. 2019).

On the other hand, some medicinal plants also confirmed a protective effect against GEN nephrotoxicity. C. sativus belongs to the genus Crocus, family Iridaceae and grows in the Eastern Mediterranean region. Iran, Morocco, Italy, and Spain are the largest producers of saffron ( Khan et al. 2020). The stigma of the saffron is well known for its antioxidant, antimicrobial (Lahmass et al. 2018), anti-inflammatory (Hosseinzadeh and Younesi 2002), and anti-depression (Moshiri et al. 2006) activities. Currently, $C$. sativus is only valued by its stigmas and much of the saffron byproducts such as tepals and stamens are not used and are usually discarded during stigma development (Sánchez-Vioque et al. 2012a). Recently, some pharmacological studies have been suggested the medicinal values of saffron tepals extract and found hepatoprotective (Ouahhoud et al. 2021; Omidi et al. 2014), antidepressant (Akhondzadeh Basti et al. 2007), anti-oxidant (Sánchez-Vioque et al. 2012b; Wali et al. 2020), and antifungal (Khoulati et al. 2019) properties. Till now the medicinal properties of stamens is poorly studied. Therefore, the present study has been carried out to valorize the renoprotective effect of $C$. sativus stamens against the GM-induced nephrotoxicity in Wistar rats.

\section{Materials and Methods}

\subsection{Chemical Compounds.}

Gentamicin sulfate (GEN) was purchased from Sigma-Aldrich Chemicals (St.Louis, MO, USA). Standard kits for urea, creatinine, and sodium assay were purchased from Biosystems, Spain. Thiobarbituric acid (TBA), Trichloroacetic acid (TCA), Glutathione, and hydrogen peroxide $\left(\mathrm{H}_{2} \mathrm{O}_{2}\right)$ were purchased from Sigma Chemicals, Germany. All other reagents used in this work were of high quality and analytical grade.

\subsection{Plants material and extract preparation}

C. sativus plants were collected from Oujda-East of Morocco in 2019. The collected plants' specimen was identified by the trained taxonomist and deposited in the herbarium of the Department of Biology, Mohamed First University, Oujda, Morocco under the reference number HUMPOM210. The stamens were collected manually during the period between late October and early November. For obtaining the methanolic extracts, the stamens were dried at room temperature and after drying the stamens were powdered, from this $50 \mathrm{~g}$ of powder was macerated in $500 \mathrm{ml}$ of $80 \%$ methanol (Merck Company, Germany) for 24 hours at room temperature (Montoro et al. 2012). This was followed by the filtration of the extract by a paper filter and evaporated in a rotary evaporator at $40{ }^{\circ} \mathrm{C}$ and finally, the obtained extracts were stored at $-20^{\circ} \mathrm{C}$ until their use. This operation was repeated several times to prepare a sufficient amount of extract. The selected concentrations were prepared by the dissolving extract in distilled water.

\subsection{Animals}

Twenty male and female Wistar rats (weight $250 \pm 30 \mathrm{~g}$ ) were collected and acclimatized for seven days in wire cages at constant temperature $\left(21 \pm 2^{\circ} \mathrm{C}\right)$ and in a $12 \mathrm{~h} \mathrm{light/dark} \mathrm{cycle} \mathrm{with} \mathrm{free}$ access to food and water at the animal house of the Department of Biology, Faculty of Sciences, Oujda. Rats were cared for in compliance with the internationally accepted guideline for the care 
and use of laboratory animals, published by the US National Institutes of Health.

\subsection{Experimental Protocol}

Rats were randomly assigned to four equal groups and each group has five animals. Among the assigned groups, animals of group 1 received only vehicle (distilled water $1 \mathrm{ml} / \mathrm{kg}$ ) and served as a control, animals of group 2 were intraperitoneally (i.p.) injected by the gentamicin $(80 \mathrm{mg} / \mathrm{kg})$ for 15 days, animals of the group 3 orally received a methanolic extract of $C$. sativus stamens at a dose of $250 \mathrm{mg} / \mathrm{kg}$ body weight and after two hours, $80 \mathrm{mg} / \mathrm{kg}$; GEN was injected i.p. to rats for 15days, similarly, animals of the group 4 orally received the higher dose of $C$. sativus stamens methanolic extract (500 mg/kg body weight), and after two hours, $80 \mathrm{mg} / \mathrm{kg}$, GEN was injected i.p. to rats for 15 days.

\subsection{Collection and analysis of urine}

To evaluate the diuretic activity, total urine volume and dietary intake were measured at the start $\left(\mathrm{T}_{0}\right)$ and end of the experiment for all rats groups. All animals were kept separately in metabolic cages, and after 24 hours urine samples were collected on days 0 and 15 of the establishment of the treatment (Ouahhoud et al. 2019). After determining the urine volume, the samples were stored at $-20{ }^{\circ} \mathrm{C}$, and were analyzed for creatinine, urea, total protein, and electrolytes, including sodium with the help of Architect Ci 4100 Analyzer.

\subsection{Sample collection and Biochemical assays}

Twenty-four hours after the last dose of intraperitoneal injection of gentamicin, all animals were anesthetized under a light ethyl ether and sacrificed. The blood samples were collected from the abdominal aorta and were put into dry blood collection tubes (Bernardi et al. 1996). Then, the blood was centrifuged at $4{ }^{\circ} \mathrm{C}$ for $10 \mathrm{~min}$ at $3000 \mathrm{rpm}$ to separate the plasma. Thereafter, the collected plasma sample was stored at $-20{ }^{\circ} \mathrm{C}$ until biochemical analysis.

\subsection{Determination of lipid peroxidation}

Malondialdehyde (MDA) is a biomarker commonly used to estimate lipid. peroxidation. In this study, MDA level was determined from the kidney tissue as per the method of Draper \& Hadley (1990). The excised kidneys were rinsed in $0.9 \% \mathrm{NaCl}$ and homogenized in iced phosphate buffer $(0.1 \mathrm{M}, \mathrm{pH}$ 7.4). Each supernatant from the organ homogenate extract $(0.5 \mathrm{ml})$ is mixed with $1 \mathrm{ml}$ of trichloroacetic acid (TCA 30\%) and centrifuged at $2500 \mathrm{rpm}$ for 10 minutes. After this, $1 \mathrm{ml}$ of $0.67 \%$ solution of thiobarbituric acid (TBA), and $0.5 \mathrm{ml}$ of supernatant are incubated for 15 minutes at a temperature of $90^{\circ} \mathrm{C}$. The absorbance of the TBA-MDA complex was determined at $532 \mathrm{~nm}$ by using a double beam UV Visible spectro-photometer (UV-Visible spectrophotometer $\mathrm{T} 80+$ ). Lipid peroxidation was expressed in $\mathrm{nmol}$ of MDA produced per gram (g tissue/mg of protein) using the $1.56 \times 10^{5} \mathrm{M}$ molar extinction coefficient:

\subsection{Determination of catalase activity (CAT)}

Catalases are present in a large number of tissues. They are tetrameric enzymes involved in the cell's defenses against oxidative stress (Aebi 1984). The enzymatic reaction is initiated by adding to $20 \mu \mathrm{l}$ the tissue homogenate prepared in a $100 \mathrm{mM}$ phosphate buffer solution $(\mathrm{pH}=7.5)$, the substrate $\mathrm{H}_{2} \mathrm{O}_{2}$ at a concentration of $0.5 \mathrm{M}$. The amount of the supernatant $(\mathrm{S})$ must be determined according to the amount of protein, which should be between 1 and $1.5 \mathrm{mg}$ an amount of 10 to $20 \mu \mathrm{l}$ of diluted supernatant. Then, monitoring the degradation of $\mathrm{H}_{2} \mathrm{O}_{2}$ to $\mathrm{O}_{2}$ at $240 \mathrm{~nm}$ by using a double beam UV Visible spectro-photometer (UV-Visible spectrophotometer T80+) after $15 \mathrm{~s}$ and $60 \mathrm{~s}$ of this addition. The catalase activity was determined according to the below formula, and the results are expressed in $\mu \mathrm{mol}$ of $\mathrm{H}_{2} \mathrm{O}_{2}$ per minute and $\mathrm{mg}$ of protein. The catalase activity is determined according to the following relationship: IU/g $=((2.3033) / \Delta T) x$ $(\log \mathrm{A} 1 / \mathrm{A} 2)$. Here, A1: Absorbance in after 15 seconds, A2: Absorbance after 1 minute, T: Interval of time per minute.

\subsection{Assessment of histopathology}

The histopathological analysis of the kidneys of all animals was performed to examine microscopically the lesions. Pieces of a kidney from each group were immediately fixed in $10 \%$ neutral formalin and dehydrated in alcohol (50 100\%), embedded in paraffin, and cut into $4 \sim 5 \mu \mathrm{m}$ thick sections using the Leica RM2235 hand-rotated microtome. These sections were stained with hematoxylin-eosin. Tissue damages in kidneys, cortex, external and internal medulla were studied using optical microscopy (Optika microscopy, Italy). The ratio of glomerulus dilation/ Bowman space in all groups was estimated using "MESURIM_PRO" software, the scale was taken from "Optika microscopy digital USB camera" microscopic imaging software, and the Bowman's space/glomerulus ratio was calculated using the following formula:

$$
\text { Ratio }=(\mathrm{BSA} / \mathrm{GS}) * 100
$$

Here, $\mathrm{BSA}=$ Bowman's space area in $\mathrm{mm}^{2} ; \mathrm{GS}=$ Glomerulus surface $\mathrm{mm}^{2}$

\subsection{Statistical analyses}

The results are expressed as mean \pm standard error of the mean (SEM) and were analyzed by Graph Pad Prism 5 Software using one-way ANOVA to compare the multiple-group. $\mathrm{P}<0.05$ was considered statistically significant. 
Table 1 Effect of methanolic extract on the kidney weight and the body weight change on gentamicin induced nephrotoxicity in Wistar rats

\begin{tabular}{|c|c|c|c|c|}
\hline \multirow{2}{*}{ Groups } & \multicolumn{2}{|c|}{ Average relative kidneys weight $(\mathrm{g} / \mathrm{Kg})$} & \multicolumn{2}{|c|}{$\%$ body weight change } \\
\hline & Right kidney & Left kidney & Day 7 & Day 14 \\
\hline Control & $3.33 \pm 0.16$ & $3.12 \pm 0.19$ & $+7.09 \pm 1.24$ & $+11.62 \pm 0.52$ \\
\hline GEN $(80 \mathrm{mg} / \mathrm{kg})$ & $3.67 \pm 0.11$ & $4.00 \pm 0.15 *$ & $+3.66 \pm 2.47$ & $+9.76 \pm 2.87$ \\
\hline $\begin{array}{c}250 \mathrm{mg} / \mathrm{kg} \text { extract + GEN } \\
(80 \mathrm{mg} / \mathrm{kg})\end{array}$ & $3.88 \pm 0.22$ & $3.91 \pm 0.18$ & $+8.04 \pm 1.53$ & $+12.12 \pm 3.62$ \\
\hline $\begin{array}{c}500 \mathrm{mg} / \mathrm{kg} \text { extract + GEN } \\
(80 \mathrm{mg} / \mathrm{kg})\end{array}$ & $3.64 \pm 0.24$ & $3.65 \pm 0.27$ & $+8.98 \pm 1.56$ & $+12.68 \pm 3.87$ \\
\hline
\end{tabular}

The data are expressed as mean \pm SEM $(\mathrm{n}=5) ;{ }^{*} \mathrm{P}<.05,{ }^{* *} \mathrm{P}<.01$ compared to the control group; $250 \mathrm{mg} / \mathrm{kg}$ methanolic extract + GEN 80 $\mathrm{mg} / \mathrm{kg}$, while $500 \mathrm{mg} / \mathrm{kg}$ methanolic extract + GEN $80 \mathrm{mg} / \mathrm{kg}$

Table 2 Effect of methanolic extract treatment on the urinary volume, hydric intake, and dietary intake.

\begin{tabular}{|c|c|c|c|}
\hline Groups & $\begin{array}{l}\text { urinary volume } \\
(\mathrm{ml} / 24 \mathrm{~h})\end{array}$ & $\begin{array}{l}\text { Hydric intake } \\
(\mathrm{ml} / 24 \mathrm{~h})\end{array}$ & $\begin{array}{l}\text { Dietary intake } \\
(\mathrm{g} / 24 \mathrm{~h})\end{array}$ \\
\hline Control & $13.1 \pm 0.6^{\# \#}$ & $31 \pm 1.6^{\#}$ & $30.5 \pm 3.4$ \\
\hline GEN $(80 \mathrm{mg} / \mathrm{kg})$ & $24 \pm 2.6 * *$ & $48 \pm 4.6$ & $37.88 \pm 2.1$ \\
\hline $250 \mathrm{mg} / \mathrm{kg}+\mathrm{GEN}(80 \mathrm{mg} / \mathrm{kg})$ & $9.2 \pm 0.8^{\# \#}$ & $42 \pm 3.2$ & $30.28 \pm 3.2$ \\
\hline $500 \mathrm{mg} / \mathrm{kg}+\mathrm{GEN}(80 \mathrm{mg} / \mathrm{kg})$ & $13.2 \pm 1.6^{\#}$ & $44 \pm 2.1$ & $40.88 \pm 1.1$ \\
\hline
\end{tabular}

The data are expressed as mean \pm SEM $(\mathrm{n}=5) ;{ }^{*} \mathrm{P}<.05,{ }^{* *} \mathrm{P}<.01$ compared to the control group; ${ }^{\#} \mathrm{P}<.05,{ }^{\# \#} \mathrm{P}<.01$ Compared to the GEN group; $250 \mathrm{mg} / \mathrm{kg}$ methanolic extract + GEN $80 \mathrm{mg} / \mathrm{kg}$, while $500 \mathrm{mg} / \mathrm{kg}$ methanolic extract + GEN $80 \mathrm{mg} / \mathrm{kg}$

\section{Results}

\subsection{Effect of extract treatment on body and kidney weight}

The results related to the body and kidney weight revealed that daily injection of gentamicin $(80 \mathrm{mg} / \mathrm{Kg})$ and the treatment with 250 and $500 \mathrm{mg} / \mathrm{kg} /$ day of the methanolic extract did not induce any significant change in the bodyweight of rats compared to the control (Table 1). Furthermore, no significant change was reported in the weight of the right kidney in the mice treated with $C$. sativus methanolic extract as compared to the control group while the weight of the left kidneys in rats treated with GEN showed some increases as compared to the control group. However, the mice treated with the $C$. sativus methanolic extract did not induce a significant increase in the left kidney weight as compared to the GEN group

\subsection{Effect of extract treatment on urinary volume, hydric intake, and dietary intake}

Table 2 showed that water intake was significantly decreased in the untreated control. While in the extract-treated rats, the water ratio was less than in the rats treated with GEN groups. The volume of $24 \mathrm{hrs}$ urine samples was also higher in the untreated rats than in the control $(p<0.01)$. In contrast, the treatment with methanolic extract at 250 and $500 \mathrm{mg} / \mathrm{kg}$ significantly reduced the urinary volume as compared to the untreated GEN group $(\mathrm{p}<0.01$ and $\mathrm{p}<0.05$ respectively). Further, food intake remained consistent in the control rats, as well as in the treated and untreated groups.

\subsection{Effect of extract treatment on biochemical parameters of serum}

Table 3 depicted the effect of $C$. sativus stamens methanolic extracts $(250$ and $500 \mathrm{mg} / \mathrm{kg}$ ) on the serum levels of urea, creatinine, and sodium concentration in rats injected with gentamicin. When compared to the standard control, serum urea and creatinine levels in the GEN group increased significantly $(p<0.05)$. In addition, rats injected with gentamicin and then treated with methanolic extract at a dose of $250 \mathrm{mg} / \mathrm{kg}$ showed a significant $(\mathrm{p}<0.01)$ decrease in serum urea and creatinine levels as compared to the GEN treated groups. Further, rats treated with the higher dose of $C$. sativus stamens methanolic extracts $(500 \mathrm{mg} / \mathrm{kg}$ ) remarkably reduced $(\mathrm{p}<0.01)$ the serum creatinine and urea level $(\mathrm{p}<0.05)$ as compared to the GEN group. Besides, the treatment with the methanolic extract reduces the levels of creatinine and urea for both doses $(\mathrm{p}<0.01)$ as compared to the controls. Table 3 also suggested that the GEN reduced serum sodium levels compared to control while the treatment with both extracts $(250$, $500 \mathrm{mg} / \mathrm{kg})$ significantly improves $(\mathrm{p}<0.01, \mathrm{p}<0.05)$ the serum sodium levels compared to the GEN group, respectively. Besides, the extract at $250 \mathrm{mg} / \mathrm{kg}$ significantly $(\mathrm{p}<0.05)$ increases serum sodium compared to controls. 
Table 3 Effect of methanolic extract on the serum level of urea, creatinine and sodium in GEN-treated rats.

\begin{tabular}{|c|c|c|c|}
\hline Groups & $\begin{array}{l}\text { Serum creatinine } \\
(\mathrm{mg} / \mathrm{dl})\end{array}$ & Blood urea nitrogen $(\mathrm{mg} / \mathrm{dl})$ & $\begin{array}{l}\text { Blood Sodium Level } \\
(\mathrm{nmol} / \mathrm{l})\end{array}$ \\
\hline Control & $0.60 \pm 0.01$ & $35.4 \pm 1.3$ & $150.8 \pm 7.7$ \\
\hline GEN $(80 \mathrm{mg} / \mathrm{kg})$ & $0.66 \pm 0.01 *$ & $36.6 \pm 0.7 *$ & $138.8 \pm 2.9$ \\
\hline $250 \mathrm{mg} / \mathrm{kg}+\mathrm{GEN}(80 \mathrm{mg} / \mathrm{kg})$ & $0.51 \pm 0.02^{\# \# *}$ & $29.2 \pm 1.5^{\# \# * *}$ & $181.2 \pm 6.7^{\# \# *}$ \\
\hline $500 \mathrm{mg} / \mathrm{kg}+\mathrm{GEN}(80 \mathrm{mg} / \mathrm{kg})$ & $0.53 \pm 0.005^{\# \# * * *}$ & $30.2 \pm 2.4^{\#}$ & $174.4 \pm 13.7^{\#}$ \\
\hline
\end{tabular}

The data are expressed as mean \pm SEM $(\mathrm{n}=5) ;{ }^{*} \mathrm{P}<.05,{ }^{* *} \mathrm{P}<.01$ compared to the control group; ${ }^{\#} \mathrm{P}<.05,{ }^{{ }^{\#}} \mathrm{P}<.01$ Compared to the GEN group; $250 \mathrm{mg} / \mathrm{kg}$ methanolic extract + GEN $80 \mathrm{mg} / \mathrm{kg}$, while $500 \mathrm{mg} / \mathrm{kg}$ methanolic extract + GEN $80 \mathrm{mg} / \mathrm{kg}$

Table 4 Effect of methanolic extract on the urinary level of urea, creatinine and sodium in GEN-treated rats.

\begin{tabular}{|cccc|}
\hline Groups & $\begin{array}{c}\text { Urine creatinine } \\
(\mathrm{mg} / 24 \mathrm{~h})\end{array}$ & $\begin{array}{c}\text { Urine urea nitrogen }(\mathrm{mg} / 24 \mathrm{~h}) \\
\text { Urine sodium } \\
(\mathrm{nmol} / 24 \mathrm{~h})\end{array}$ & $234.4 \pm 16.4$ \\
\hline Control & $703.3 \pm 63.8$ & $3816 \pm 157.06$ & $140.8 \pm 9.5$ \\
\hline GEN $(80 \mathrm{mg} / \mathrm{kg})$ & $318.6 \pm 24.5^{*}$ & $1822.2 \pm 107.9$ & $225.2 \pm 30.8^{\#}$ \\
\hline Extract $1(250 \mathrm{mg} / \mathrm{kg})+\mathrm{GEN}(80 \mathrm{mg} / \mathrm{kg})$ & $589.05 \pm 50.6^{\#}$ & $3078.4 \pm 318.9^{\#}$ & $204.6 \pm 23.8^{\#}$ \\
\hline Extract $2(500 \mathrm{mg} / \mathrm{kg})+\mathrm{GEN}(80 \mathrm{mg} / \mathrm{kg})$ & $482.9 \pm 48.8^{\#}$ & $2565.4 \pm 346.5$ & ${ }^{\#}$ \\
\hline
\end{tabular}

The data are expressed as mean \pm SEM $(\mathrm{n}=5) ;{ }^{*} \mathrm{P}<.05$, compared to the control group; ${ }^{\#} \mathrm{P}<.05$, Compared to the GEN group; $250 \mathrm{mg} / \mathrm{kg}$ methanolic extract + GEN $80 \mathrm{mg} / \mathrm{kg}$, while $500 \mathrm{mg} / \mathrm{kg}$ methanolic extract + GEN $80 \mathrm{mg} / \mathrm{kg}$.

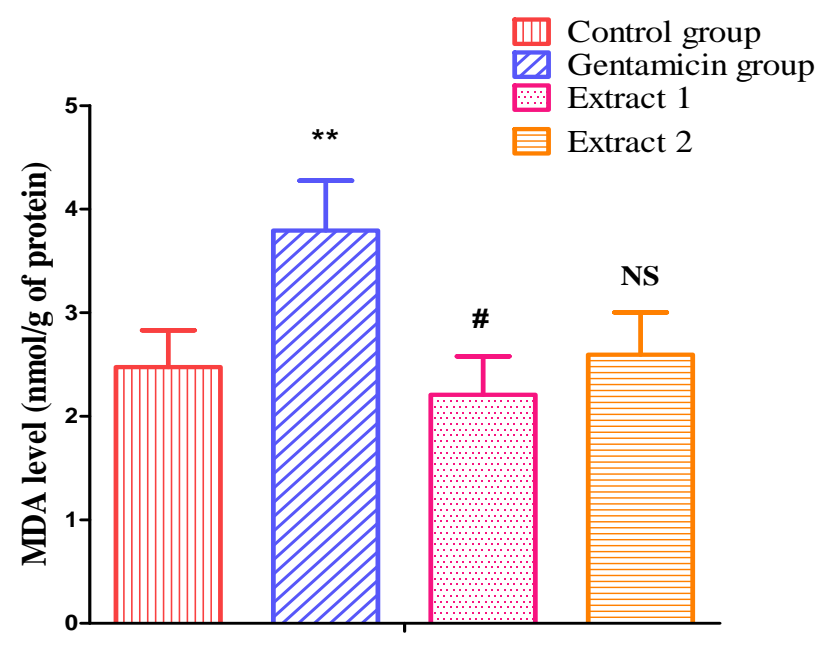

Figure 1 Effect of methanolic extract of the Crocus sativus stamens on MDA production in the kidneys of GEN-treated rats. Extract 1: methanolic extract $(250 \mathrm{mg} / \mathrm{kg}+\mathrm{GEN} 80 \mathrm{mg} / \mathrm{kg})$, extract 2 : methanolic extract $(500 \mathrm{mg} / \mathrm{kg}+\mathrm{GEN} 80 \mathrm{mg} / \mathrm{kg}) .{ }^{*} \mathrm{P}<.05,{ }^{*} * \mathrm{P}<.01 \mathrm{compared}$ to the control group. \#P $<.05$, Compared to the GEN group. NS. Not significantly different Compared to the GEN group.

3.4 Effect of extract treatment on urinary biochemical parameter

Table 4 indicates that the daily injection of gentamicin $(80 \mathrm{mg} / \mathrm{Kg})$ caused a significant $(\mathrm{p}<0.05)$ decrease in the concentration of urinary creatinine and no significant reduction was reported in the urinary urea and sodium as compared to the control. While, a significant elevation was observed in creatinine, urea, and sodium levels in the urine of rats intoxicated with GEN and treated with the extract at $250 \mathrm{mg} / \mathrm{ml}$ compared to the GEN group $(\mathrm{P}<0.05)$. The extract at a dose of $500 \mathrm{mg} / \mathrm{ml}$ significantly $(\mathrm{P}<0.05)$ increased the creatinine and sodium levels while no significant changes were reported in the level of urea as compared to the control.

\subsection{Effect of extract treatment on oxidative stress marker and antioxidant enzyme activities}

Figure 1summarized the protective effects of $C$. sativus stamens methanolic extract on MDA production in the kidneys of GENtreated rats. Lipoperoxidation is manifested in the GEN group by a significant increase in MDA ( $p<0.01$ ), compared to the control 


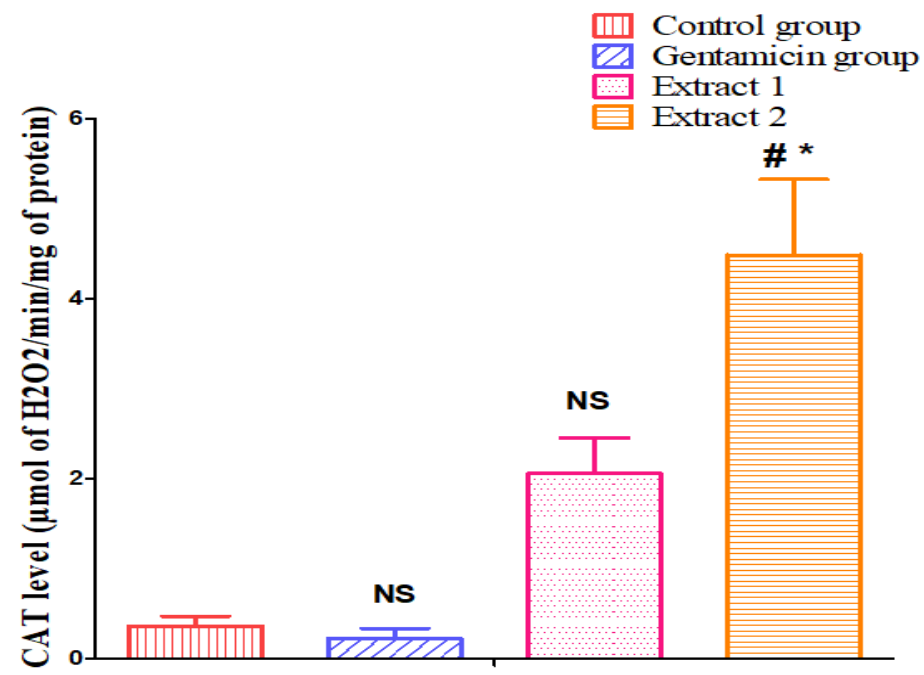

Figure 2 Effect of methanolic extract of the Crocus sativusstamens on catalase activity of GEN-treated rats. Extract 1: methanolic extract $(250 \mathrm{mg} / \mathrm{kg}+\mathrm{GEN} 80 \mathrm{mg} / \mathrm{kg})$, extract 2: methanolic extract $(500 \mathrm{mg} / \mathrm{kg}+\mathrm{GEN} 80 \mathrm{mg} / \mathrm{kg})$. Values are expressed as mean $\pm \mathrm{SD}(\mathrm{n}=5)$. " $\mathrm{P}<.05$ compared to the control group. \#P $<.05$, Compared to the GEN group. NS. Not significantly different Compared to the GEN group.

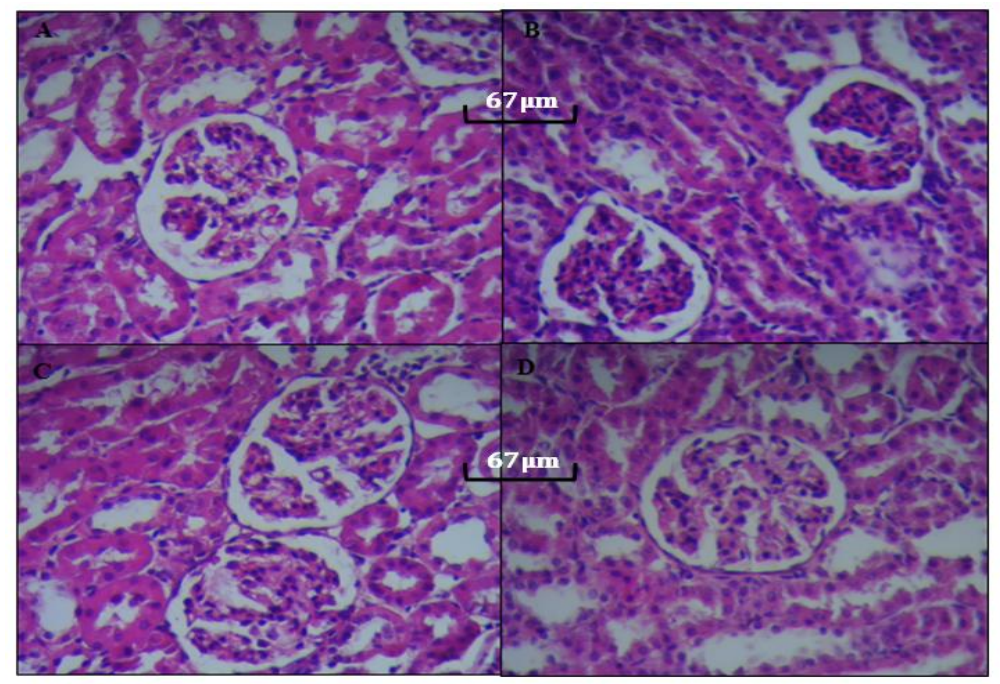

Figure 3 Photomicrographs of rat's kidneys from different experimental groups stained with H\&E. Normal histopathological view of a renal section in control rats (A), the treatment with Gentamicin sulfate $(80 \mathrm{mg} / \mathrm{kg} / \mathrm{day})$ shows degeneration, tubular necrosis, and dilation,

glomeruli hypertrophy (B). Section from rat treated with GEN ( $80 \mathrm{mg} / \mathrm{kg} /$ day) plus methanolic extract ( $250 \mathrm{mg} / \mathrm{kg} / \mathrm{day})$ reveal near to normal structure (C). Renal sections of GEN $80 \mathrm{mg} / \mathrm{kg}$ + methanolic extract $500 \mathrm{mg} / \mathrm{kg}$ renal sections showed a remarkable recovery of the glomerulus with tubules with moderate Bowman's capsule dilation (D).

group. Treatment with methanolic extract at a concentration of 250 $\mathrm{mg} / \mathrm{ml}$ significantly $(\mathrm{p}<0.05)$ decreases the lipid oxidation in rats, whereas $500 \mathrm{mg} / \mathrm{ml}$ concentration has a non-significant effect on the reduction of MDA value in the control group. Furthermore, figure 2 suggested that GEN administration caused a decrease in the activity of the defensive enzymes CAT compared to the control group. Although methanolic extract at $250 \mathrm{mg} / \mathrm{kg}$ treatment caused an insignificant increase in the CAT activity in the GENtreated group compared with the non-treated GEN group, while methanolic extract $500 \mathrm{mg} / \mathrm{kg}$ induced a significant increase in renal CAT of GEN-treated rats $(\mathrm{P}<0.05)$.

\subsection{Effect of extract treatment on histopathological alterations in the kidney cell}

Figure 3 depicted the sections of renal tissue light microscopic examination from each animal group. Histopathological assessment of gentamicin treated group kidneys showed massive 


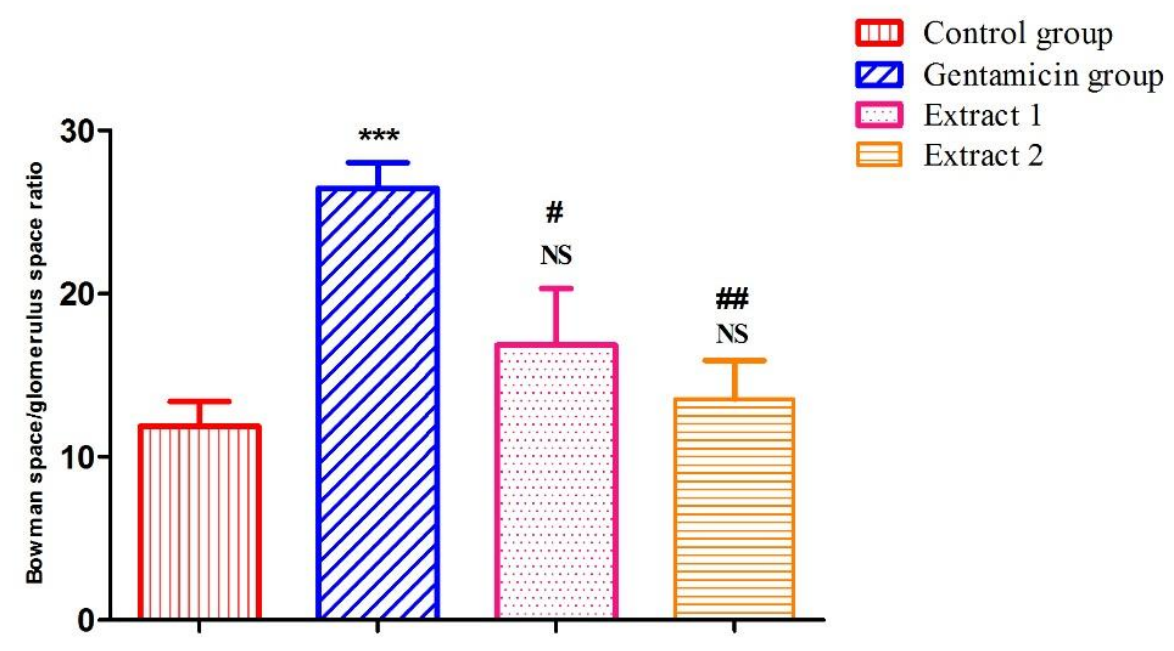

Figure 4 Effect of Methanolic extract Crocus sativus stamens on o glomerulus dilation/ Bowmanspace ratio in the kidney of gentamicin sulfate-treated rats. Extract 1: methanolic extract $(250 \mathrm{mg} / \mathrm{kg}+\mathrm{GEN} 80 \mathrm{mg} / \mathrm{kg})$, extract 2: methanolic extract (500 mg/kg + GEN $80 \mathrm{mg} / \mathrm{kg})$.

Values are expressed as mean $\pm \mathrm{SD}(\mathrm{n}=5) .{ }^{*} \mathrm{P}<.05{ }^{* * *} \mathrm{P}<.001$ compared to the control group. ${ }^{\#} \mathrm{P}<.05,{ }^{{ }^{* \prime}} \mathrm{P}<.01$, Compared to the GEN group. NS. Not significantly different compared to control group.

and severe damage. Gentamicin induced renal injury that caused tubular necrosis and dilation. Further, glomeruli hypertrophy showed multifocal renal tubular degeneration and coagulative necrosis in the cortex. Figure 4 suggested that the Bowman space/glomerulus ratio increases significantly $(p<0.001)$ in the GEN treated group as compared to the control group. This means that GEN induces glomerulus dilatation and also causes some alterations in the basement membrane and expansion of the Bowman capsule. However, treatment with $C$. sativus stamens methanolic extract at variable doses has a significant protective effect $(p<0.01)$ against GEN-induced glomerulus damage. In mice treated with GEN + higher dose of methanolic extract (500 $\mathrm{mg} / \mathrm{kg}$ ) renal sections showed a remarkable recovery of the glomerulus with tubules with moderate Bowman's capsule dilation.

\section{Discussion}

Aminoglycosides have long been used against bacterial infections and are widely used in clinical practice. However, drug-related toxicity is the main constraint to clinical treatment with aminoglycoside antibiotics, despite their positive effects (Vysakh et al. 2018). The aminoglycosides accumulate in the proximal tubule epithelial cells, causing nephrotoxicity. Due to high efficacy, gentamicin is the first choice of aminoglycosides in treating gram-negative infections (Choi et al. 2011). It induces direct nephrotoxicity through the accumulation in the renal cortex. In the current study, GEN was injected at a dose of $80 \mathrm{mg} / \mathrm{kg}$ (ip) successively for 15 days. As expected, the administration of GEN induced renal damage, which was associated with increased biochemical parameters, urea, and creatinine. This study showed that impaired renal function was correlated with increased kidney weight and these results are confirmed by the findings of Ghaznavi et al. (2016). The results of this study indicated that daily treatment of rats with a methanolic extract ( 250 and $500 \mathrm{mg} / \mathrm{kg} /$ day) for 15 days prevented GEN-induced nephrotoxicity in kidney weight.

Plasma levels of creatinine and urea are crucial parameters of kidney function. An increase in creatinine means impaired kidney function or kidney disease (Gilbert et al. 1989; Hasanvand et al. 2019; Edeogu et al. 2020). The present study showed that intraperitoneal injection of GEN $(80 \mathrm{mg} / \mathrm{kg})$ induced significant nephrotoxicity $(\mathrm{p}<0.05)$ by increasing serum creatinine, urea, sodium, and urine volume. These results are consistent with several previous studies (Raju et al. 2011; Janjua et al. 2014; Salama et al. 2020) which found that daily administration of GEN resulted in a significant elevation in serum, urine urea, and creatinine concentrations as compared to the control group.

The pathophysiology of gentamicin renal toxicity is complex and still unknown. Recent literature has shown that GEN produces reactive oxygen species (ROS) in the kidney (Choi et al. 2011; Ozbek 2012), and has induced an elevation in lipid peroxidation and a decrease in the levels of antioxidant molecules (Kang et al. 2013). Elevated levels of MDA, as an indicator of lipid peroxidation, were shown in the GEN-treated group. In contrast to this, increased MDA levels were significantly reduced $(\mathrm{p}<0.05)$ by methanolic extract of $C$. sativus stamens at $250 \mathrm{mg} / \mathrm{kg}$. Whereas at a higher concentration $(500 \mathrm{mg} / \mathrm{kg})$, the MDA value was not significantly reduced, indicating that the generation of reactive oxygen species in GEN-induced nephrotoxicity has been eliminated and mitigated the effect of lipid peroxidation. 
Interestingly, methanolic extract administered restored the renal activities and CAT level in GEN treated groups. Furthermore, the elevation in MDA and increase in CAT activities in the GEN + methanolic extract could be due to the antioxidant properties of $C$. sativus stamens extract.

After filtration, GEN as a non-metabolized element is reabsorbed by the renal tubules and enters in the tubular cells after their binding to phospholipid membrane receptors that induced structural or functional changes (Balakumar et al. 2008). Accumulation of GEN in kidney tissue leads to severe kidney damage, involving total tubular necrosis and dilatation, hypertrophy of the glomeruli is evidenced in multifocal renal tubular degeneration. Coagulant necrosis has been also observed in the cortex. In addition, some changes such as inflation and congestion have been also reported in the glomeruli, while damage to the basement membrane and expansion of Bowman's capsule was also reported during the study. These findings are in agreement with the results of Josiah et al. (2020) and Okokon et al (2011). The histopathological results confirmed the changes in the biochemical parameters. Simultaneous administration of methanolic extracts improved the GEN-induced alterations in the renal tubules and glomeruli. Antioxidant compounds show a preventive effect against gentamicin-induced toxicity in rat kidneys (Khan et al. 2009). C. sativus stamens is a by-product generated during stigma collection has been evaluated as a potent antioxidant compound (Montoro et al. 2012).

\section{Conclusion}

Results of the study can be concluded that treatment with both the concentrations of methanolic extract would decrease and prevent GEN-induced nephrotoxicity in rats. Administration of methanolic extract resulted in a significant decrease in kidney weight, biochemical parameters, as well as CAT and MDA concentrations in the kidneys. These results suggest the antioxidant properties of C. sativus stamens methanolic extract may cause the renoprotective effect.

\section{Author contributions}

All the authors have accepted responsibility for the entire content of this submitted manuscript and approved submission.

\section{Conflicts of Interest}

The authors declared no potential conflicts of interest to the research, authorship, and/or publication of this article.

\section{Acknowledgments}

The authors wish to express their appreciation to Badraoui Mustapha for their technical assistance.

\section{References}

Aebi, H. (1984). Catalase in vitro. Methods in Enzymology, 105, 121-126.

Akhondzadeh Basti, A., Moshiri, E., Noorbala, A.A., Jamshidi, A.H., Abbasi, S.H., \& Akhondzadeh, S. (2007). Comparison of petal of Crocus sativus L. and fluoxetine in the treatment of depressed outpatients: a pilot double-blind randomized trial. Progress in Neuro-Psychopharmacology \& Biological Psychiatry, 31(2), 439-442.

Ali, B. H. (2003). Agents ameliorating or augmenting experimental gentamicin nephrotoxicity: some recent research. Food and Chemical Toxicology, 41(11), 1447-1452.

Balakumar, P., Chakkarwar, V. A., Kumar, V., Jain, A., Reddy, J., \& Singh, M. (2008). Experimental models for nephropathy. Journal of the Renin-Angiotensin-Aldosterone System, 9(4), 189195.

Bernardi, C., Monetal, D., Brughera, M., Di Salvo, M., Lamparelli, D., Mazué, G., \& Iatropoulos, M. J. (1996). Haematology and clinical chemistry in rats: Comparison of different blood collection sites. Comparative Haematology International, 6(3), 160-166. 0

Choi, J. J., Moffett, B. S., McDade, E. J., \& Palazzi, D. L. (2011). Altered gentamicin serum concentrations in obese pediatric patients. The Pediatric Infectious Disease Journal, 30(4), 347-349.

Conly, J. M., Gold, W., \& Shafran, S. D. (1994). Once-Daily Aminoglycoside Dosing: A New Look at an Old Drug. Canadian Journal of Infectious Diseases, 5, 796138.

Draper, H. H., \& Hadley, M. (1990). Malondialdehyde determination as index of lipid peroxidation. Methods in Enzymology, 186, 421-431.

Edeogu, C. O., Kalu, M. E., Famurewa, A. C., Asogwa, N. T., Onyeji, G. N., \& Ikpemo, K. O. (2020). Nephroprotective Effect of Moringa Oleifera Seed Oil on Gentamicin-Induced Nephrotoxicity in Rats: Biochemical Evaluation of Antioxidant, Antiinflammatory, and Antiapoptotic Pathways. Journal of the American College of Nutrition, 39(4), 307-315.

Ghaznavi, H., Fatemi, I., Kalantari, H., Hosseini Tabatabaei, S. M. T., et al. (2018). Ameliorative effects of gallic acid on gentamicininduced nephrotoxicity in rats. Journal of Asian Natural Products Research, 20(12), 1182-1193.

Ghaznavi, H., Mehrzadi, S., Dormanesh, B., Tabatabaei, S. M. T. H., et al. (2016). Comparison of the protective effects of melatonin and silymarin against gentamicin-induced nephrotoxicity in rats. 
Journal of Evidence-Based Complementary \& Alternative Medicine, 21(4), NP49-NP55.

Ghuysen, M. S. (2005). Les médicaments dangereux pour le rein. Archives de Pédiatrie, 390(6), 643 YP - 1059.

Gilbert, D. N., Wood, C. A., Kohlhepp, S. J., Kohnen, P. W., et al. (1989). Polyaspartic acid prevents experimental aminoglycoside nephrotoxicity. Journal of Infectious Diseases, 159(5), 945-953.

Hasanvand, A., Tavafi, M., Ahmadvand, H., \& Tamjidipoor, A. (2019). Effect of dimethyl sulfoxide in combat with gentamicin induced nephrotoxicity in rats. Journal of Nephropathology, 9(3), e26.

Hosseinzadeh, H., \& Younesi, H. M. (2002). Antinociceptive and anti-inflammatory effects of Crocus sativus L. stigma and petal extracts in mice. BMC Pharmacology, 2, 7.

Huang, J., Li, J., Lyu, Y., Miao, Q., \& Pu, K. (2019). Molecular optical imaging probes for early diagnosis of drug-induced acute kidney injury. Nature Materials, 18(10), 1133-1143.

Janjua, A., Waheed, A., \& Bakhtiar, S. (2014). Protective effect of metformin against gentamicin induced nephrotoxicity in rabbits. Pakistan Journal of Pharmaceutical Sciences, 27(6), 1863-1872.

Josiah, S. S., Crown, O. O., Akinmoladun, A. C., \& Olaleye, M. T. (2020). Renoprotective property of the flavonoid-rich extract of Kigelia africana fruits on gentamicin-induced nephrotoxicity in rats. Comparative Clinical Pathology, 29(4), 815-828.

Kang, C., Lee, H., Hah, D. Y., Heo, J. H., et al. (2013). Protective effects of Houttuynia cordata Thunb. on gentamicin-induced oxidative stress and nephrotoxicity in rats. Toxicological Research, 29(1), 61-67.

Karie, S., Launay-Vacher, V., Deray, G., \& Isnard-Bagnis, C. (2010). Toxicité rénale des médicaments. Néphrologie \& Thérapeutique, 6(1), 58-74.

Khan, M., Hanif, M. A., Ayub, M. A., Jilani, M. I., \& Shahid Chatha, S. A. (2020). Saffron. In Hanif, M.A., Nawaz, H., Khan, M.M., Byrne, H.J. (eds), Medicinal Plants of South Asia (pp. 587-600), Elsevier Publication.

Khan, S. A., Priyamvada, S., Farooq, N., Khan, S., Khan, M. W., \& Yusufi, A. N. K. (2009). Protective effect of green tea extract on gentamicin-induced nephrotoxicity and oxidative damage in rat kidney. Pharmacological Research, 59(4), 254-262.
Khoulati, A., Ouahhoud, S., Mamri, S., Alaoui, K., et al. (2019). Saffron extract stimulates growth, improves the antioxidant components of Solanum lycopersicum L., and has an antifungal effect. Annals of Agricultural Sciences, 64(2), 138-150.

Lahmass, I., Ouahhoud, S., Elmansuri, M., Sabouni, A., et al. (2018). Determination of Antioxidant Properties of Six ByProducts of Crocus sativus L. (Saffron) Plant Products. Waste and Biomass Valorization, 9(8), 1349-1357.

Montoro, P., Maldini, M., Luciani, L., Tuberoso, C. I. G., Congiu, F., \& Pizza, C. (2012). Radical scavenging activity and LC-MS metabolic profiling of petals, stamens, and flowers of Crocus sativus L. Journal of Food Science, 77(8), C893-900.

Morales-Alvarez, M. C. (2020). Nephrotoxicity of Antimicrobials and Antibiotics. Advances in Chronic Kidney Disease, 27(1), 3137.

Moshiri, E., Basti, A. A., Noorbala, A.A., Jamshidi, A.H., Hesameddin Abbasi, S., \& Akhondzadeh, S. (2006). Crocus sativus $\mathrm{L}$. (petal) in the treatment of mild-to-moderate depression: a double-blind, randomized and placebo-controlled trial. Phytomedicine: International Journal of Phytotherapy and Phytopharmacology, 13(9-10), 607-611.

Okokon, J. E., Nwafor, P. A., \& Noah, K. (2011). Nephroprotective effect of Croton zambesicus root extract against gentimicin-induced kidney injury. Asian Pacific Journal of Tropical Medicine, 4(12), 969—972.

Omidi, A., Riahinia, N., Montazer Torbati, M. B., \& Behdani, M.A. (2014). Hepatoprotective effect of Crocus sativus (saffron) petals extract against acetaminophen toxicity in male Wistar rats. Avicenna Journal of Phytomedicine, 4(5), 330-336.

Ouahhoud, S., Touiss, I., Khoulati, A., Lahmass, I., et al. (2021). Hepatoprotective effects of hydroethanolic extracts of Crocus sativus tepals, stigmas and leaves on carbon tetrachloride induced acute liver injury in rats. Physiology \& Pharmacology, 25(2), 10.32598/ppj.25.2.30.

Ouahhoud, S., Lahmass, I., Bouhrim, M., Khoulati, A., et al. (2019). Antidiabetic effect of hydroethanolic extract of Crocus sativus stigmas, tepals and leaves in streptozotocin-induced diabetic rats. Physiology and Pharmacology, 23 (1) :9-20.

Ozbek, E. (2012). Induction of oxidative stress in kidney. International Journal of Nephrology, 2012, 465897.

Raju, S., Kavimani, S., Uma Maheshwara rao, V., Sreeramulu Reddy, K., \& Vasanth Kumar, G. (2011). Floral extract of Tecoma 
stans: A potent inhibitor of gentamicin-induced nephrotoxicity in vivo. Asian Pacific Journal of Tropical Medicine, 4(9), 680-685.

Reiter, R. J., Tan, D.X., Sainz, R. M., Mayo, J. C., \& LopezBurillo, S. (2002). Melatonin: reducing the toxicity and increasing the efficacy of drugs. The Journal of Pharmacy and Pharmacology, 54(10), 1299-1321.

Salama, A. A., Abd El-Wahed, A. S., \& Mostafa, A. E. (2020). Protective effect of some plants against the toxicity of kidneys caused by gentamicin. Journal of Medicine in Scientific Research, $3(1), 5$.

Sánchez-Vioque, R., Rodríguez-Conde, M. F., Reina-Ureña, J. V., Escolano-Tercero, M. A., Herraiz-Peñalver, D., \& SantanaMéridas, O. (2012a). In vitro antioxidant and metal chelating properties of corm, tepal and leaf from saffron (Crocus sativus L.). Industrial Crops and Products, 39(1), 149-153.

Sánchez-Vioque, R., Rodríguez-Conde, M. F., Reina-Ureña, J. V, Escolano-Tercero, M. A., Herraiz-Peñalver, D., \& SantanaMéridas, O. (2012b). In vitro antioxidant and metal chelating properties of corm, tepal and leaf from saffron (Crocus sativus L.). Industrial Crops and Products, 39, 149-153.

Vysakh, A., Abhilash, S., Kuriakose, J., Midhun, S. J., Jyothis, M., \& Latha, M. S. (2018). Protective effect of Rotula aquatica Lour against gentamicin induced oxidative stress and nephrotoxicity in Wistar rats. Biomedicine \& Pharmacotherapy, 106, 1188-1194.

Wali, A. F., Alchamat, H. A. A., Hariri, H. K., Hariri, B. K., et al. (2020). Antioxidant, Antimicrobial, Antidiabetic and Cytotoxic Activity of Crocus sativus L. Petals. Applied Sciences, 10(4), 1519. 